\title{
PENCIPTAAN FILM ANIMASI “AFEKSI" DENGAN TEKNIK DIGITAL 2 DIMENSI MELALUI PENDEKATAN SUREALIS
}

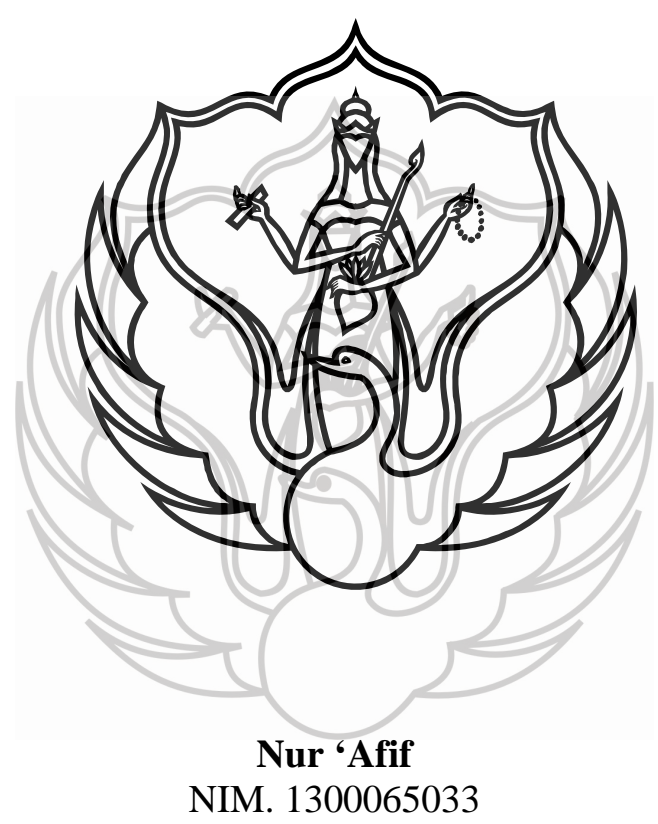

PROGRAM STUDI D-3 ANIMASI

JURUSAN TELEVISI

FAKULTAS SENI MEDIA REKAM INSTITUT SENI INDONESIA YOGYAKARTA

2017

UPT Perpustakaan ISI Yogyakarta 


\section{PENCIPTAAN FILM ANIMASI “AFEKSI” DENGAN TEKNIK DIGITAL 2 DIMENSI MELALUI PENDEKATAN SUREALIS}

LAPORAN TUGAS AKHIR

untuk memenuhi sebagian persyaratan

mencapai derajat Ahli Madya

Program Studi D-3 Animasi

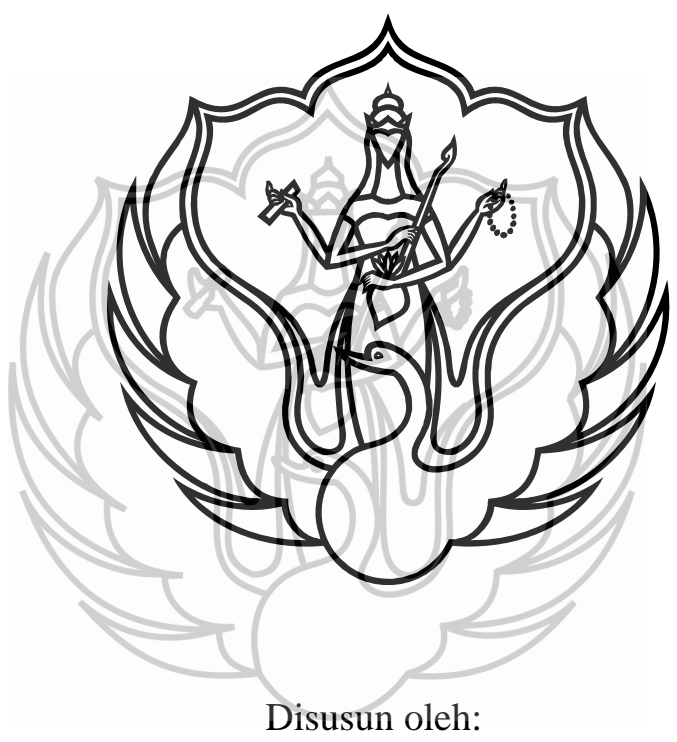

Nur'Afif

NIM. 1300065033

PROGRAM STUDI D-3 ANIMASI

JURUSAN TELEVISI

FAKULTAS SENI MEDIA REKAM

INSTITUT SENI INDONESIA YOGYAKARTA

2017

\section{UPT Perpustakaan ISI Yogyakarta}




\section{HALAMAN PENGESAHAN}

Laporan Tugas Akhir yang berjudul:

\section{PENCIPTAAN FILM ANIMASI "AFEKSI" DENGAN TEKNIK DIGITAL 2 DIMENSI MELALUI PENDEKATAN SUREALIS}

Disusun oleh:

\section{Nur 'Afif}

NIM. 1300065033

Pameran, penayangan, dan laporan tertulis Tugas Akhir karya seni animasi telah dipertanggungjawabkan di depan Tim Penguji Tugas Akhir Program Studi D-3 Animasi, Jurusan Televisi, Fakultas Seni Media Rekam, Institut Seni Indonesia Yogyakarta, pada tanggal ….......$A \cdot A \cdot 2.017$

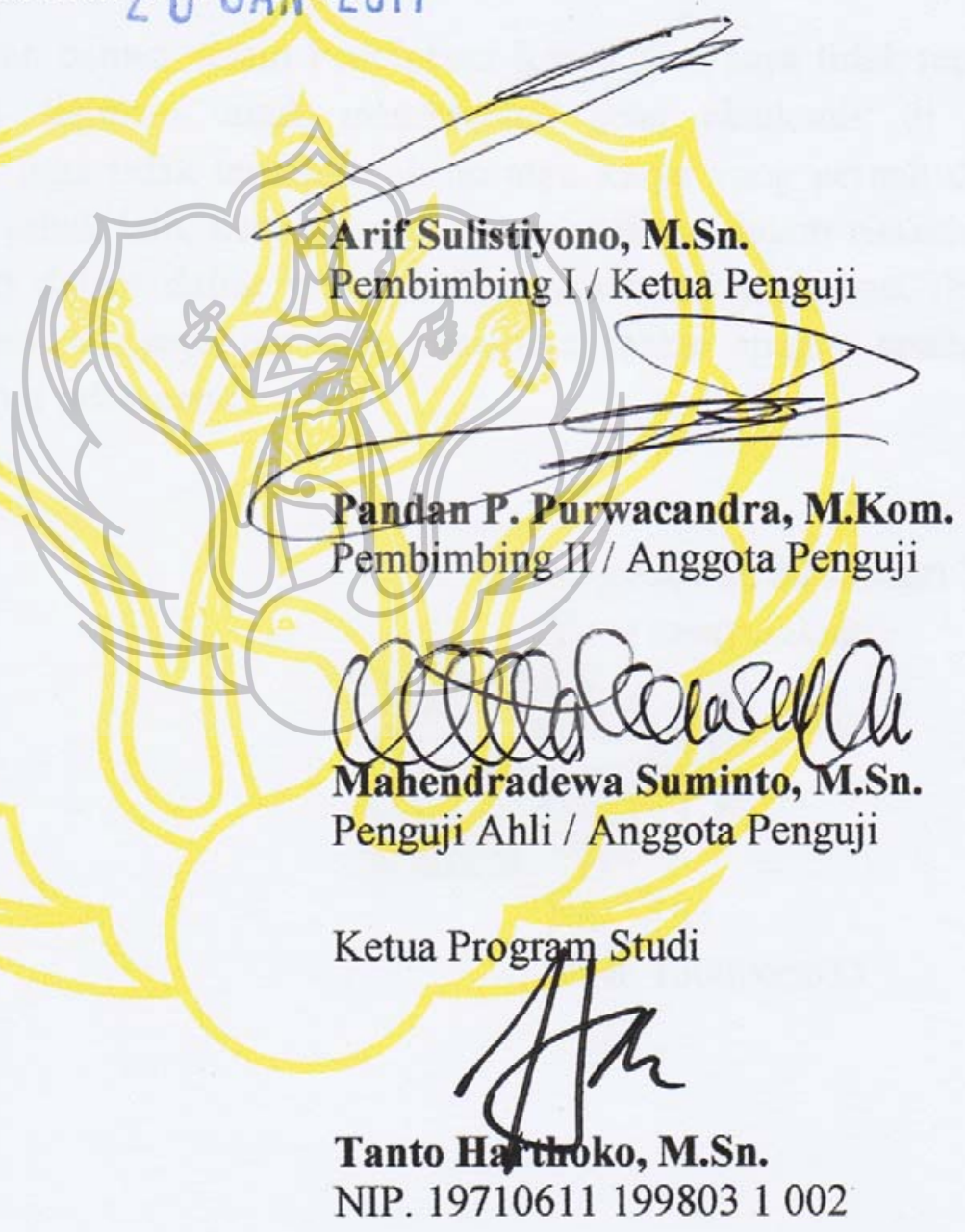

Mengetahui,

Dekan

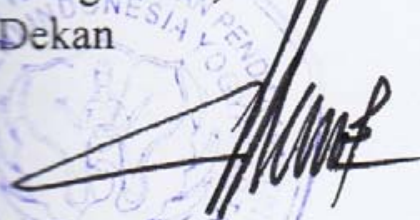

Marsudi, S.Kar., M.Hum.

सiP 196107101987031002

NIP. 197106111998031002

\section{UPT Perpustakaan ISI Yogyakarta}




\section{HALAMAN PERNYATAAN}

Yang bertanda-tangan di bawah ini,

\begin{tabular}{|c|c|}
\hline Nama & Nur 'Afif \\
\hline No. Induk Mahasiswa & 1300065033 \\
\hline Judul Tugas Akhir & $\begin{array}{l}\text { PENCIPTAAN FILM ANIMASI "AFEKSI" } \\
\text { DENGAN TEKNIK DIGITAL } 2 \text { DIMENSI } \\
\text { MELALUI PENDEKATAN SUREALIS }\end{array}$ \\
\hline
\end{tabular}

Dengan ini menyatakan bahwa dalam Penciptaan Karya Seni saya tidak terdapat bagian yang pernah diajukan untuk memperoleh gelar akademik di suatu perguruan tinggi dan juga tidak terdapat tulisan atau karya yang pernah ditulis atau diproduksi oleh pihak lain, kecuali secara tertulis diacu dalam naskah atau karya dan disebutkan dalam daftar pustaka. Pernyataan ini saya buat dengan penuh tanggung jawab dan saya bersedia menerima sanksi apapun apabila di kemudian hari diketahui tidak benar.

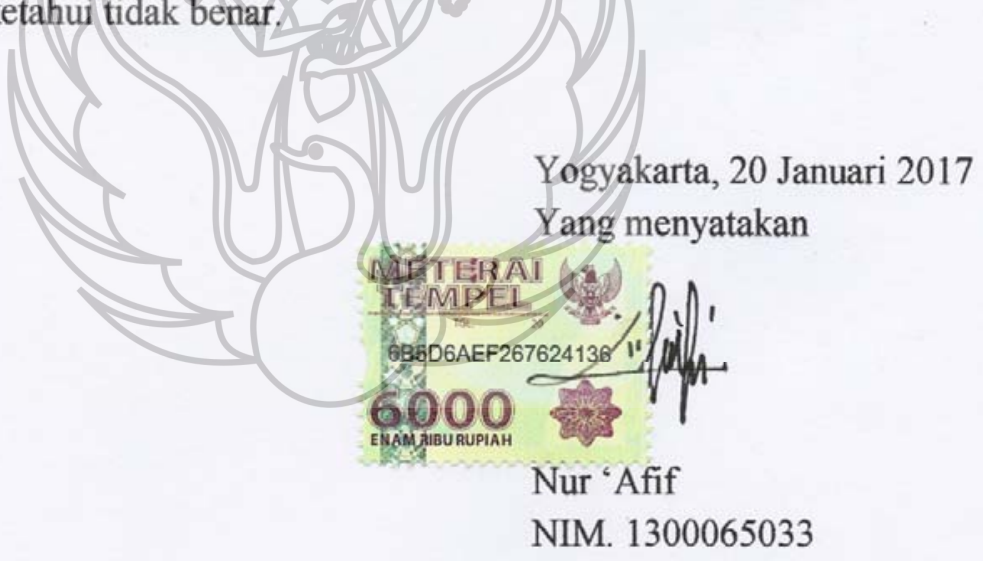

\section{UPT Perpustakaan ISI Yogyakarta}




\section{KATA PENGANTAR}

Puji syukur atas segala nikmat Tuhan Yang Maha Esa, yang telah memberikan rahmat kasih sayang-Nya, sehingga sampai pada detik ini masih diberikan kesehatan dan kelancaran guna menyelesaikan proses belajar. Segala proses belajar, berkesenian dan berkarya selama tujuh semester baik dalam hal akademik maupun non-akademik dapat dituangkan dalam sebuah penciptaan karya seni tugas akhir. Penciptaan karya seni tugas akhir film animasi “Afeksi” dengan teknik digital 2D melalui pendekatan surealis ini sebagai syarat kelulusan Program Studi D-3 Animasi, Jurusan Televisi, Fakultas Seni Media Rekam, ISI Yogyakarta.

Karya seni tugas akhir ini menjadi cerminan nyata, bahwa akhir itu bukanlah akhir yang sebenarnya melainkan awal pijakan berproses dan berkesenian di luar sana. Dibalik/sebuah karya seni, dibalik cara berkesenian, emosi, tangis, tawa, doa akan senantiasa menjadi pelengkap tersendiri di setiap langkah yang dijalani.

Karya tugas akhir penciptaan film animasi “Afeksi” tidak akan tercipta tanpa adanya dukungan yang luar biasa dari banyak pihak. Terima kasih banyak disampaikan kepada:

Ucapan terimakasih juga diucapkan kepada:

1. Kedua orang tua Ayah dan Ibu tercinta, yang memberikan doa, motivasi dan kasih sayang serta materil;

2. Institut Seni Indonesia Yogyakarta;

3. Dr. M. Agus Burhan, M.Hum., selaku Rektor Institut Seni Indonesia Yogyakarta;

4. Marsudi S.Kar., M.Hum., selaku Dekan Fakultas Seni Media Rekam, Institut Seni Indonesia Yogyakarta;

5. Tanto Harthoko, M.Sn., selaku Ketua Program Studi D-3 Animasi,

6. Mahendradewa Suminto, M.Sn., selaku penguji ahli;

\section{UPT Perpustakaan ISI Yogyakarta}


7. Arif Sulistiyono, M.Sn., selaku dosen pembimbing I;

8. Pandan Pareanom Purwacandra, M.Kom., selaku dosen pembimbing II;

9. Samuel Gandang Gunanto, M.T., selaku dosen wali;

10. Uswatun Kumalasari, staf akademik Program Studi D-3 Animasi, Jurusan Televisi, Fakultas Seni Media Rekam, ISI Yogyakarta;

11. Seluruh staf pengajar dan karyawan Program Studi D-3 Animasi, Jurusan Televisi, Fakultas Seni Media Rekam, ISI Yogyakarta;

12. Kerabat kerja yang telah membantu menyelesaikan karya tugas akhir;

13. Kawan-kawan animasi ISI Yogyakarta angkatan 2013 yang luar biasa, serta kawan-kawan animasi 2012, dan 2014 yang telah memberikan dukungan;

14. Kawan-kawan kontrakan brother.

Semoga hasil akhir film animasi "Afeksi" memberikan manfaat baik dari segi karya maupun penulisan, diharapkan kritik dan saran untuk perbaikan yang membangun dimasa mendatang.

Yogyakarta,

Nur 'Afif 


\begin{abstract}
ABSTRAK
Afeksi merupakan bahasa Indonesia dari kamus ilmiah yang berarti kasih sayang. Kasih sayang yang diangkat dalam film animasi ini adalah kasih sayang antara ibu dan seorang putra yang dibesarkannya. Konflik dan emosional diantara keduanya hadir kala si anak menuju kedewasaan, ketidakstabilan emosi saat remaja dalam menghadapi berbagai filosofi dan realitas kehidupan. Hal inilah yang menjadikan pemisah jarak dan waktu, hingga sesal, sepi dan rindu yang menuntunnya kembali kepada sang ibu.

Penciptaan film animasi ini disajikan dalam bentuk animasi 2D dengan teknik pencahayaan hardlight tanpa menggunakan narasi dan dialog. Sebagai penunjangnya dibangunlah musik sedemikian rupa sehingga dapat memperkuat suasasa dalam setiap alurnya.

Visualisasi film sengaja mengusung konsep tarian teatrikal kontemporer dimana dari segi konten maupun gerak masih menyisipkan unsur budaya. Tidak lupa pendekatan surealis juga diterapkan dalam karya ini. Penambahan elemen air sebagai wujud penekanan ekspresi dan emosional sekaligus untuk menambahkan kesan artistik sebagai penunjang visualisasi.
\end{abstract}

Kata kunci: afeksi, animasi 2D, surealis, teatrikal

\title{
UPT Perpustakaan ISI Yogyakarta
}




\section{DAFTAR ISI}

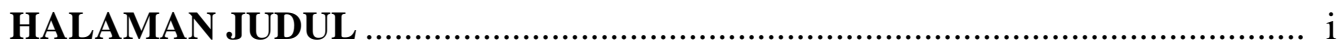

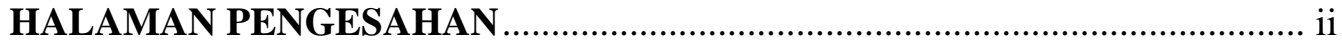

SURAT PERNYATAAN ..............................................................................ii

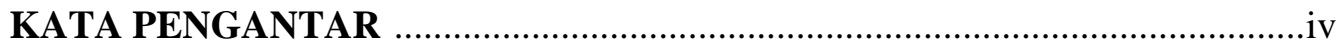

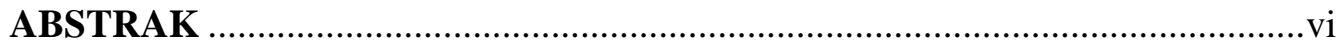

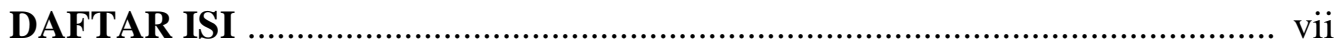

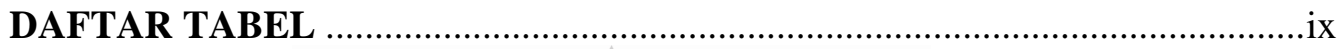

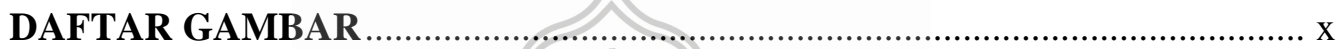

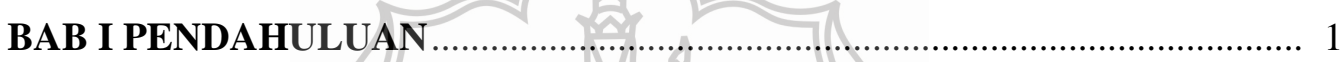

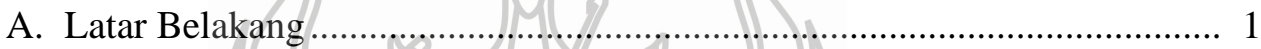

B. Rumusan Masalah .......................................................................... 3

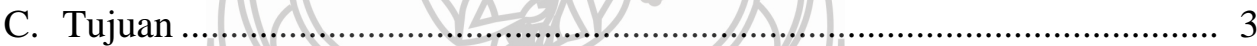

D. Target Audiens............................................................................ 3

E. Indikator Capaian Akhir ..................................................................... 3

1. Pra Produksi .......................................................................... 4

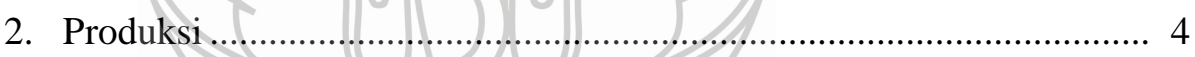

3. Pasca Produksi ............................................................................... 6

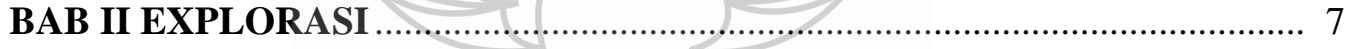

A. Landasan Teori................................................................................. 7

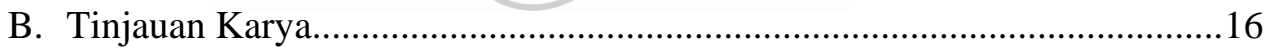

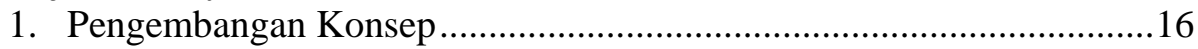

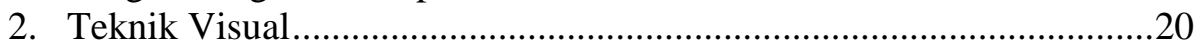

a. Desain Karakter ........................................................................20

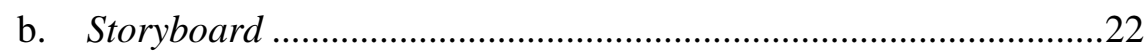

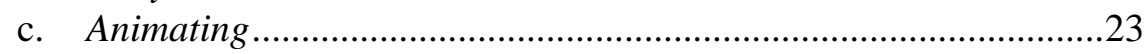

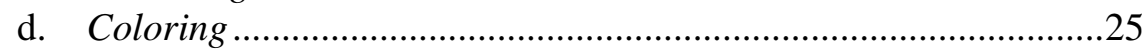

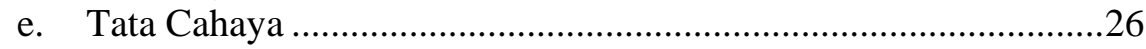

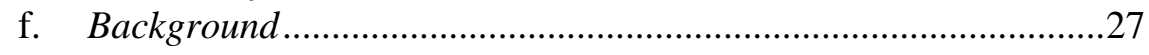

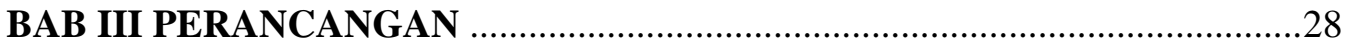

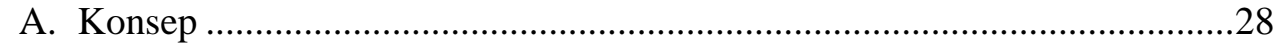

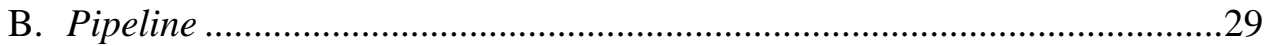

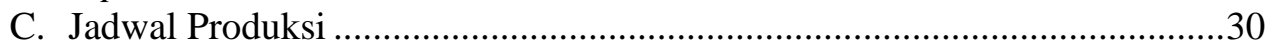

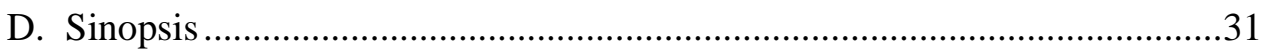

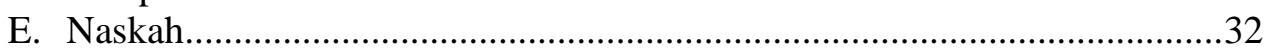

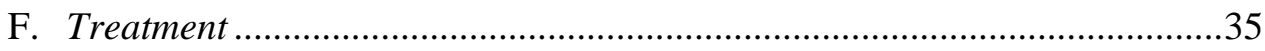




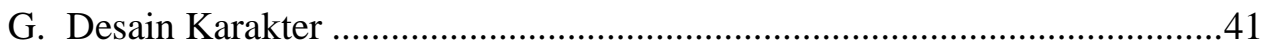

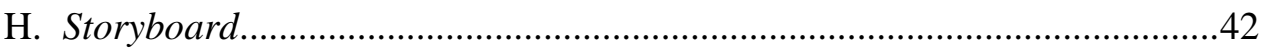

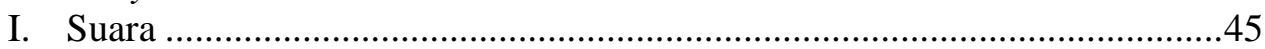

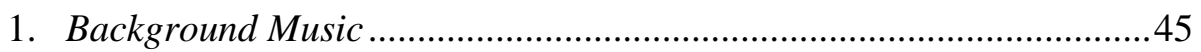

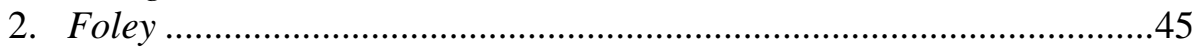

J. Hardware dan Software .....................................................................45

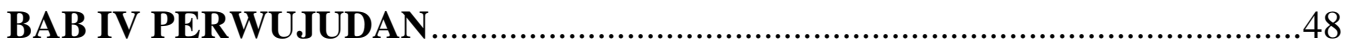

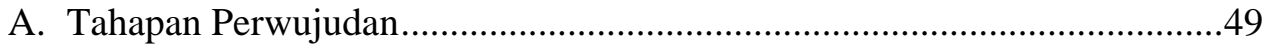

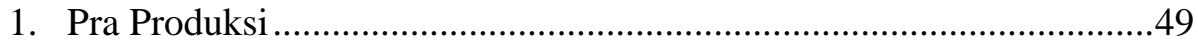

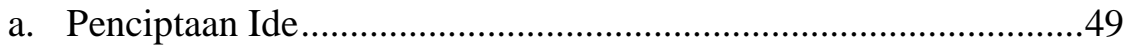

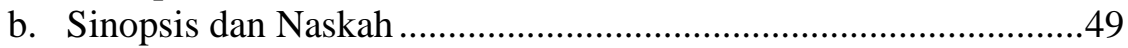

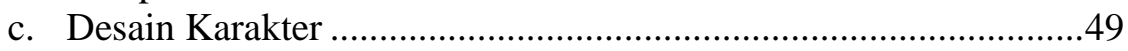

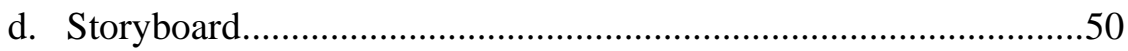

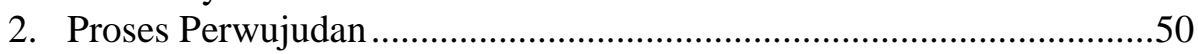

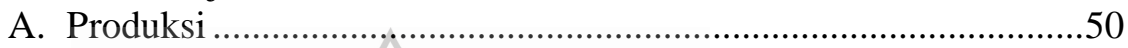

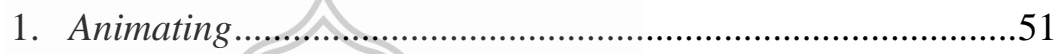

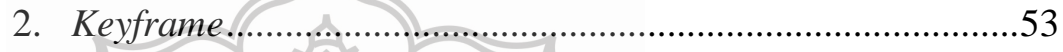

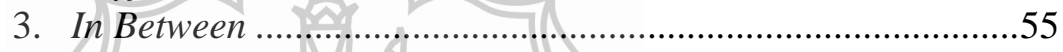

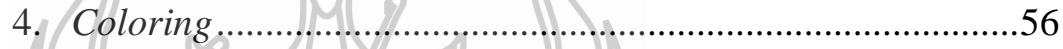

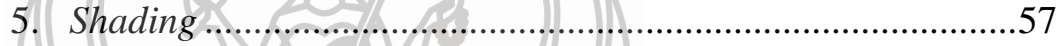

6. Sequence Rendering .........................................................58

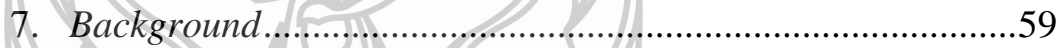

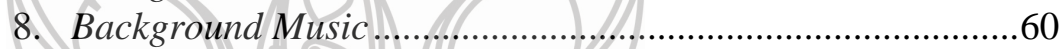

B. Pasca Produksi ..................................................................62

1. Compose ...................................................................62

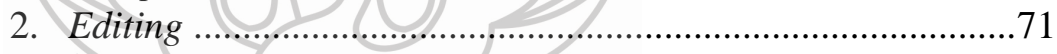

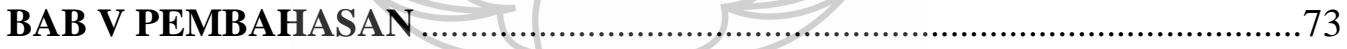

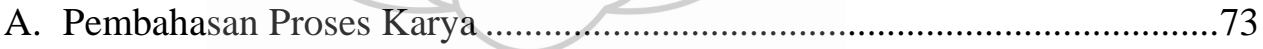

B. Pembahasan Penerapan 12 Prinsip.............................................................74

C. Pembahasan Perbandingan Tinjauan Karya...............................................82

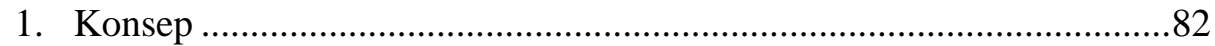

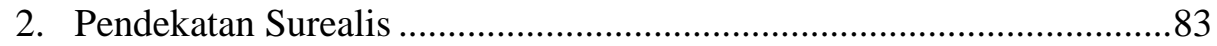

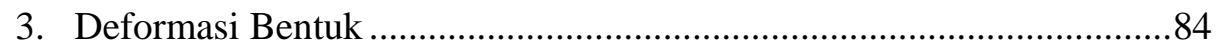

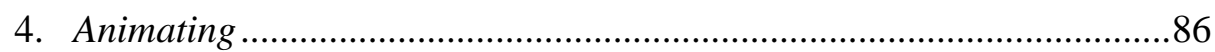

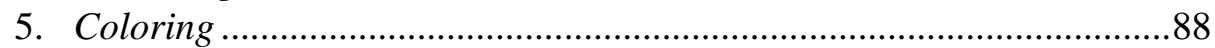

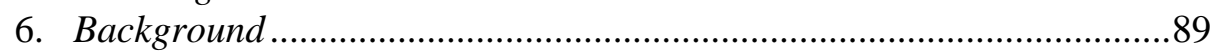

D. Pembahasan Analisis Pembiayaan ...........................................................90

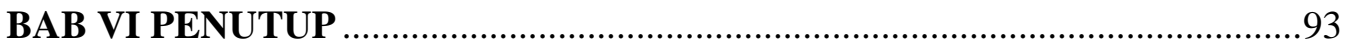

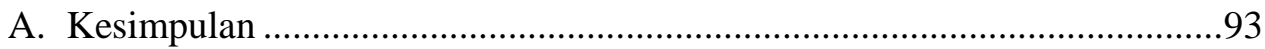

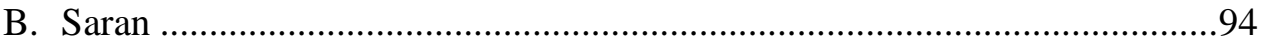

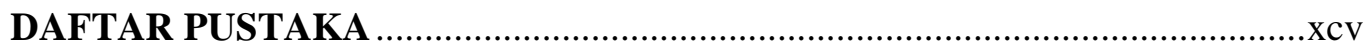

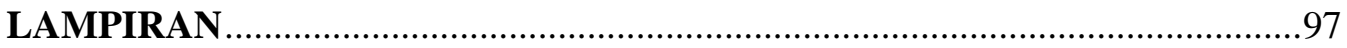

viii 


\section{DAFTAR TABEL}

Tabel 3. 1 Pipeline produksi film animasi “Afeksi” ...............................................30

Tabel 3. 2 Jadwal Produksi film animasi "Afeksi” .....................................................31

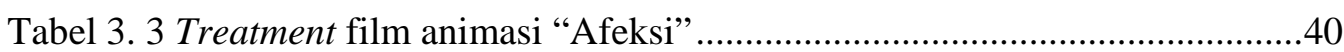

Tabel 4. 1 Data frame dan shot film "Afeksi” .......................................................64

Tabel 4. 2 Data spesifik shot 01 film "Afeksi” .........................................................65

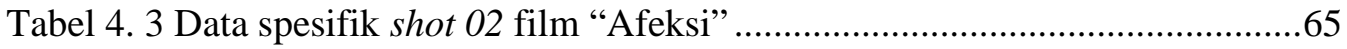

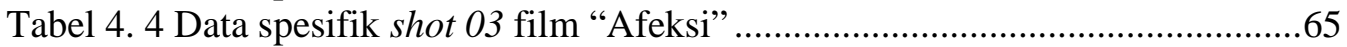

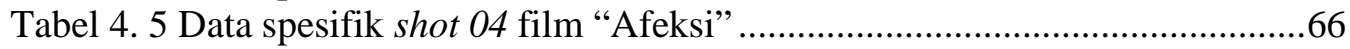

Tabel 4. 6 Data spesifik shot 05 film "Afeksi” ..........................................................66

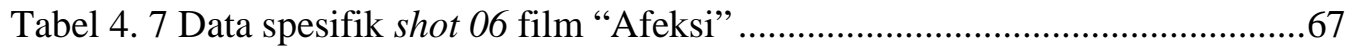

Tabel 4. 8 Data spesifik shot 07 film "Afeksi" ......................................................67

Tabel 4. 9 Data spesifik shot 08 film "Afeksi” ...................................................67

Tabel 4. 10 Data spesifik shot 09 film "Afeksi” .......................................................68

Tabel 4. 11 Data spesifik shot 10 film "Afeksi” ....................................................68

Tabel 4. 12 Data spesifik shot 12 film "Afeksi” ....................................................69

Tabel 4. 13 Data spesifik shot 13 film "Afeksi” ...................................................69

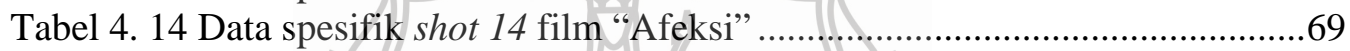

Tabel 4. 15 Data spesifik shot 15 film "Afeksi” .......................................................70

Tabel 4. 16 Data elemen 2D film “Afeksi”.......................................................70

Tabel 5. 1 Analisis biaya pengembangan film animasi "Afeksi” ..............................90

Tabel 5. 2 Analisis biaya pra produksi film animasi "Afeksi” .................................90

Tabel 5. 3 Analisis biaya produksi animasi “Afeksi” ..............................................91

Tabel 5. 4 Analisis biaya pasca produksi animasi "Afeksi" ....................................91

Tabel 5. 5 Analisis biaya overhead film animasi "Afeksi”.....................................91

Tabel 5. 6 Analisis biaya mastering film animasi “Afeksi”.......................................92

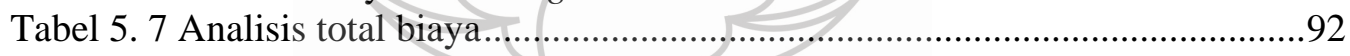

\section{UPT Perpustakaan ISI Yogyakarta}




\section{DAFTAR GAMBAR}

Gambar 2. 1 Screenshoot animasi Ryan Woodward "Thought of You" 1 ................17

Gambar 2. 2 Screenshoot animasi Ryan Woodward "Thought of You” 2 ................17

Gambar 2. 3 Screenshoot animasi Ryan Woodward "Thought of You" 3 ................17

Gambar 2. 4 Deformasi bentuk[....]"The Turtle and The Shark" 1 ...........................18

Gambar 2. 5 Deformasi bentuk[....]"The Turtle and The Shark” 2.........................18

Gambar 2. 6 Deformasi bentuk[....]"The Turtle and The Shark” 3 ...........................19

Gambar 2. 7 Deformasi bentuk animasi Glen Keane "Duet" 1.................................19

Gambar 2. 8 Deformasi bentuk animasi Glen Keane "Duet" 2...............................19

Gambar 2. 9 Deformasi bentuk animasi Glen Keane "Duet” 3................................20

Gambar 2. 10 Ideal proportion male ...............................................................21

Gambar 2. 11 Karakter animasi ketika bayi Glen Keane "Duet” ..............................21

Gambar 2. 12 Karakter animasi ketika remaja Glen Keane "Duet” ...........................22

Gambar 2. 13 Karakter animasi ketika dewasa Glen Keane "Duet”............................22

Gambar 2. 14 E-Comic "Botom of the Ninth" 1 .....................................................23

Gambar 2. 15 E-Comic "Botom of the Ninth" 2 2....................................................23

Gambar 2. 16 Penerapan onion skin[....]”Doodle-Martha Graham”..........................24

Gambar 2. 17 Efek gerakan "Official Google Doodle-Martha Graham” ...................24

Gambar 2. 18 Warna monokrom "The Tale of The Three Brother"..........................25

Gambar 2. 19 Shading 2 tingkat warna "The Cube"..............................................25

Gambar 2. 20 Tata cahaya hardlight "Estrena-American Dance Theater"................26

Gambar 2. 21 Background tekstur "Gravity-Beautyfull Love Story .........................27

Gambar 3. 1 Karakter ibu dalam film animasi “Afeksi”...........................................41

Gambar 3. 2 Karakter anak dalam film animasi "Afeksi” .....................................42

Gambar 3. 3 Potongan Storyboard shot 02-03 film animasi "Afeksi” ......................33

Gambar 3. 4 Potongan Storyboard shot 03 film animasi "Afeksi”............................44

Gambar 4. 1 Screenshoot hasil akhir tahapan produksi film "Afeksi” .......................50

Gambar 4. 2 Pengaturan FPS produksi film “Afeksi” ...............................................51

Gambar 4. 3 Fitur onion skin produksi film “Afeksi” "..............................................52

Gambar 4. 4 Palet warna produksi film “Afeksi”....................................................52

Gambar 4. 5 Ukuran pensil produksi film “Afeksi”...................................................53

Gambar 4. 6 Hasil garis pensil produksi film "Afeksi” ............................................53

Gambar 4. 7 Keyframe awal penganimasian film “Afeksi”......................................54

Gambar 4. 8 Keyframe tengah penganimasian film "Afeksi” "....................................54

Gambar 4. 9 Keyframe akhir penganimasian film "Afeksi” .......................................54

Gambar 4. 10 In between penganimasian film "Afeksi” ........................................55

Gambar 4. 11 Peg untuk stretch and squash film “Afeksi” .....................................56

Gambar 4. 12 Warna Dasar film "Afeksi” ................................................................56

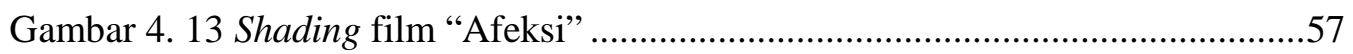

Gambar 4. 14 Hasil Akhir coloring dan shading film "Afeksi” ................................57

Gambar 4. 15 Pengaturan render PNG film "Afeksi”" ................................................58

Gambar 4. 16 Pengaturan render kualitas PNG film “Afeksi”....................................58

Gambar 4. 17 Hasil render PNG sequence anak dalam film "Afeksi”.......................59

Gambar 4. 18 Hasil render PNG sequence ibu dalam film "Afeksi” .........................59

Gambar 4. 19 Background dalam film "Afeksi” .......................................................60

\section{UPT Perpustakaan ISI Yogyakarta}


Gambar 4. 20 Ilustrasi musik film "Afeksi” 1

Gambar 4. 21 Ilustrasi musik film "Afeksi” 2 2........................................................61

Gambar 4. 22 Ilustrasi musik film "Afeksi” 3 ........................................................61

Gambar 4. 23 Composition Setting film “Afeksi”....................................................63

Gambar 4. 24 Compositing tahap pertama shot 01- shot 07 film "Afeksi” ...............63

Gambar 4. 25 Compositing tahap kedua shot 08- shot 15 film “Afeksi”....................64

Gambar 4. 26 Compositing shot 01 film "Afeksi”.................................................65

Gambar 4. 27 Compositing shot 02 film "Afeksi”....................................................65

Gambar 4. 28 Compositing shot 03 film “Afeksi” ................................................66

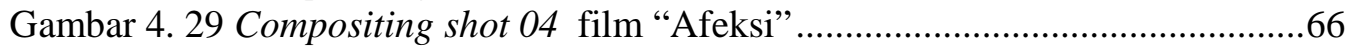

Gambar 4. 30 Compositing shot 05 film "Afeksi” "...............................................66

Gambar 4. 31 Compositing shot 06 film “Afeksi”.................................................67

Gambar 4. 32 Compositing shot 07 film "Afeksi”...................................................67

Gambar 4. 33 Compositing shot 08 film "Afeksi”...................................................68

Gambar 4. 34 Compositing shot 09 film "Afeksi”.................................................68

Gambar 4. 35 Compositing shot 10 film "Afeksi”...................................................68

Gambar 4. 36 Compositing shot 12 film "Afeksi”..................................................69

Gambar 4. 37 Compositing shot 13 film "Afeksi” .................................................69

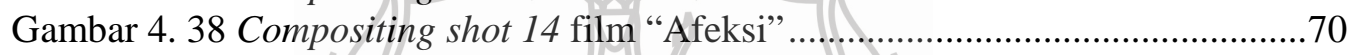

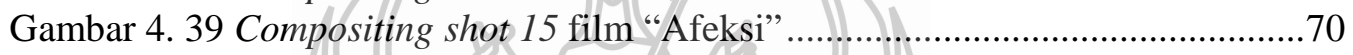

Gambar 4. 40 Editing pemberian bayangan film "Afeksi" ".....................................71

Gambar 4. 41 Editing dan Grading film "Afeksi” ................................................71

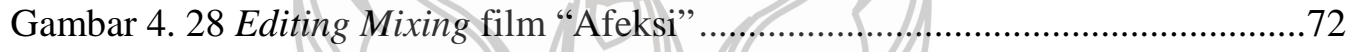

Gambar 5. 1 Anticipation pada scene 01 shot 01 film "Afeksi" ................................74

Gambar 5. 2 Squash and stretch pada scene 01 shot 01 film "Afeksi" 1 ..................75

Gambar 5. 3 Squash and stretch pada scene 01 shot 01 film "Afeksi" 2 ..................75

Gambar 5. 4 Staging tata letak tengah film "Afeksi”...............................................76

Gambar 5. 5 Pose to Pose ekstrim scene 01 shot 02 film “Afeksi”.............................76

Gambar 5.6 Follow Throught scene 01 shot 07 film "Afeksi” .................................77

Gambar 5.7 Slow in Slow out scene 01 shot 05 film "Afeksi”...................................78

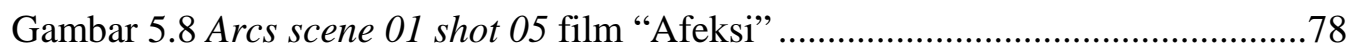

Gambar 5.9 Secondary Action scene 01 shot 05 film “Afeksi” ................................79

Gambar 5.10 Timing and Spacing scene 01 shot 10 film "Afeksi” ...........................80

Gambar 5.11 Exagerration scene 01 shot 02 film "Afeksi” ...................................80

Gambar 5.12 Exagerration scene 01 shot 07 film "Afeksi” .....................................81

Gambar 5.13 Solid Drawing scene 01 shot 01 film "Afeksi”.................................81

Gambar 5.14 Appeal karakter anak film “Afeksi” ................................................82

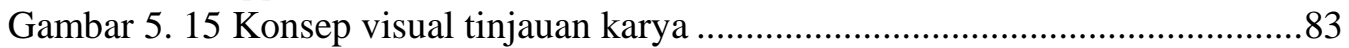

Gambar 5. 16 Konsep visual film animasi “Afeksi” ................................................83

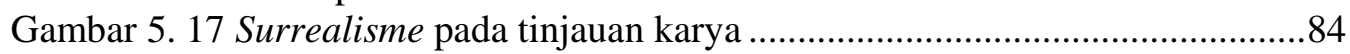

Gambar 5. 18 Surrealisme pada film animasi “Afeksi” ...........................................84

Gambar 5. 19 Deformasi bentuk pada tinjauan karya 1 .........................................85

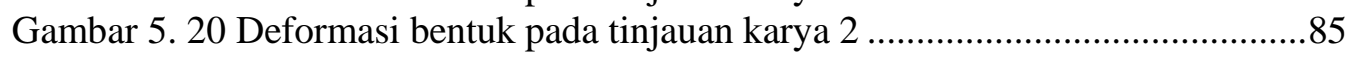

Gambar 5. 21 Deformasi bentuk pada film animasi “Afeksi” 1...............................85

Gambar 5. 22 Deformasi bentuk pada film animasi “Afeksi” 2...............................86

Gambar 5. 23 PNG sequence animasi lompatan pada tinjauan karya .........................86 
Gambar 5. 24 PNG sequence animasi lompatan pada film animasi "Afeksi”.....

Gambar 5. 25 Mempertegas gerakan animasi[....]pada tinjauan karya ......................87

Gambar 5. 26 Mempertegas gerakan animasi[...]pada film animasi “Afeksi............87

Gambar 5. 27 Warna monokrom tinjauan karya .......................................................8

Gambar 5. 28 Warna monokrom film animasi "Afeksi” ............................................88

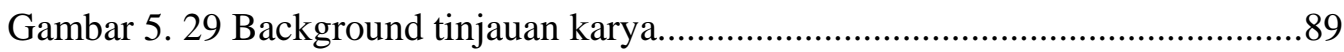

Gambar 5. 30 Background film animasi "Afeksi”.

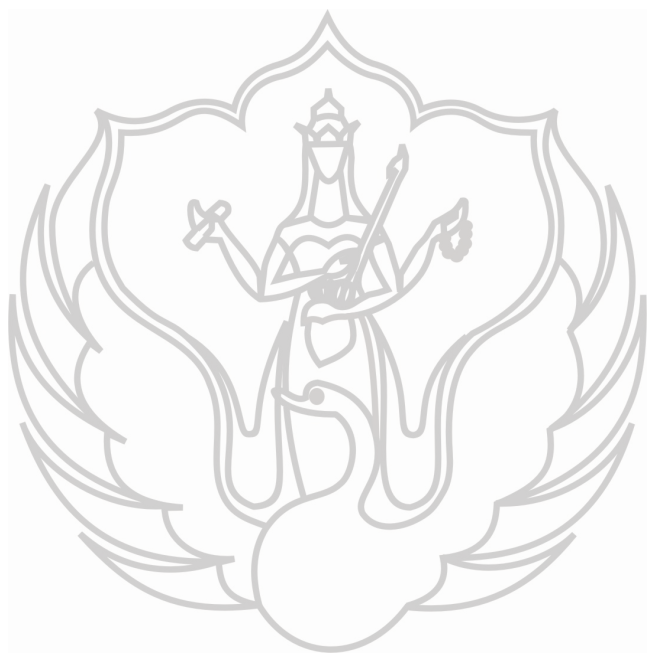




\section{BAB I \\ PENDAHULUAN}

\section{A. Latar Belakang}

Berawal dari sepenggal lagu yang dilantunkan oleh "Sisir Tanah" tentang lagu wajib. Diantara sekian banyak lirik, ada yang menjadi perhatian lebih bagi penulis. Lirik tersebut berbunyi “yang wajib dari kita adalah cinta, yang wajib dari cinta adalah mesra, yang wajib dari mesra adalah rasa, yang wajib dari rasa adalah luka, adalah luka, adalah luka”.

Melihat dari dalam aspek kehidupan, apa yang disampaikan lirik tersebut tentu benar adanya. Aspek keterkaitan antara cinta, rasa dan luka coba dikaitkan/dengan problematika sosial yang bersifat umum yakni mengikisnya cinta kasih sebagian anak kepada ibunya dewasa ini. Terlalu sibuk dengan realitas kehidupan yang sedang dijalani hingga terkadang mengesampingkan perhatian untuk sosok seorang ibu. Belum lagi beban keterbatasan jarak dan waktu yang sering terjadi khusunya bagi mereka yang sedang meniti karir. Waktu bisa menjadi pencuri, mencuri segala hal yang dicintai namun disisi lain waktu adalah anugrah di setiap detik, menit dan, jamnya.

Mengangkat sebuah pokok permasalahan yang didasari dari potret kehidupan dewasa ini, dimana efek moral dan kepedulian terutama terhadap sosok ibu yang kian memudar seiring arus. Meningkatnya berbagai tuntunan hidup dan ketidak stabilan emosi menuju kedewasaan kerap menimbulkan pemisah jarak dan waktu diantara keduanya. Walaupun konflik dengan orang tua meningkat di masa awal remaja, namun kebanyakan konflik melibatkan kejadian sehari-hari dalam kehidupan keluarga (Santrock, 2003). Dari sinilah muncul gagasan untuk menjadikan permasalahan ini sebagai konsep utama dalam penciptaan karya.

\section{UPT Perpustakaan ISI Yogyakarta}


Menyikapi permasalahan diatas, penulis bermaksud mengajak masyarakat untuk sedikitnya menumbuhkan kembali rasa cinta kasih dan kepedulian terhadap sosok ibu serta mengingatkan kembali akan seberapa banyak pengorbanan dan perhatian untuk membahagiakan anaknya. Selain persoalan diatas, memudarnya kepedulian sebagian masyarakat terhadap seni gerak juga perlu dipertimbangkan kembali. Hal tersebut dikarenakan pelestarian budaya mempunyai muatan ideologis yaitu sebagai gerakan untuk mengukuhkan kebudayaan, sejarah dan identitas (Lewis, 1983: 4), dan juga sebagai penumbuh kepedulian masyarakat untuk mendorong munculnya rasa memiliki masa lalu yang sama diantara anggota komunitas (Smith, 1996: 68). Unsur seni gerak coba disisipkan dengan mengadopsi beberapa gerakan dalam tari. Unsur tersebut/disajikan untuk memperkuat visualisasi karya animasi dua dimensi ini.

Teknik animasi dua dimensi sengaja dipergunakan karena wujud visual baik dari segi karakter maupun environment menggunakan pencahayaan hardlight bergaya semi vector. Selain aspek tersebut penulis juga mempertimbangkan kemampuan sumber daya manusia dan peralatan yang digunakan, sehingga yang paling memungkinkan adalah teknik animasi 2D tersebut. Pendekatan secara surealis dengan air sebagai bahasa perlambangan visualisasi dirasa efektif untuk mengekspresikan penekanan emosi.

Beberapa hal tersebut, melatarbelakangi penciptaan film animasi dua dimensi “Afeksi”. Cerita tentang anak laki-laki yang semakin jauh dari ibu yang senantiasa menyayanginya.

\section{UPT Perpustakaan ISI Yogyakarta}




\section{B. Rumusan Masalah}

Berdasarkan latar belakang diatas dapat dirumuskan permasalahan yang akan diselesaikan sebagai berikut:

1. Bagaimana mengembangkan ide tentang problematika sosial menjadi sebuah film animasi dua dimensi?

2. Bagaimana memproduksi dan menerapkan teknik animasi dua dimensi untuk penciptaan film animasi “Afeksi” dengan teknik digital dua dimensi melalui pendekatan surealis?

\section{Tujuan}

Tujuan dari penciptaan film animasi 2D “Afeksi” antara lain:

1. Menerapkan teknik animasi dua dimensi dalam animasi "Afeksi” dengan teknik digital dua dimensi melalui pendekatan surealis,

2. Mengekspresikan emosi dan visual tanpa belenggu dimana tercipta sesuatu yang mengejutkan.

\section{Target Audien}

Target audien menurut demografis film animasi ini adalah:
1. Usia
: 18 tahun keatas
2. Jenis kelamin
: Laki-laki dan perempuan
3. Pendidikan
: Dari latar pendidikan apapun
4. Status sosial
: Semua kalangan

\section{E. Indikator Capaian Akhir}

Hasil akhir animasi “Afeksi” adalah:
1. Judul karya
: Afeksi
2. Teknik
: Animasi 2D
3. Desain Karya
: Film Animasi
4. Durasi
: 00:02:21:10
5. Format Video
: HDTV 1920x1080 px 25 frame per second
6. Render
: format .mp4, H264 dan .MOV

\section{UPT Perpustakaan ISI Yogyakarta}


Indikator yang dicapai dalam pembuatan animasi “Afeksi” dibagi menjadi tiga tahapan, yaitu praproduksi, produksi, dan pascaproduksi.

\section{Praproduksi}

\section{a. Penulisan cerita}

Cerita ditulis dengan lengkap dan jelas mulai awal preposisi bagaimana si ibu membesarkan anaknya hingga dewasa. Bagaimana membangun raising konflik hingga puncak konflik diantara keduanya dan berakhir dengan konklusi penyelesaian yaitu sadarnya si anak betapa berartinya si ibu, yang membuat si anak kembali kepada si ibu.

b. Desain Karakter

Penciptaan karakter dan perwatakan yang disesuaikan dengan kebutuhan cerita tentu menjadi hal penunjang visual demi mempermudah tercapainya pesan dan isi dari cerita tersebut.

\section{c. Storyboard}

Storyboard dirancang sesuai naskah sebelumnya dengan mulai menggambarkan tampilan animasi, 12 prinsip animasi, jenis pengambilan kamera, sinematografi, lokasi, situasi, kondisi, ekspresi tokoh, dan durasi setiap potongan scene.

\section{Produksi}

\section{a. Animating}

Tahap ini adalah proses inti, karakter animasi dan propertinya dianimasikan satu per satu menggunakan bantuan software animasi dengan frame rate 25fps. Penganimasian menggunakan teknik $2 \mathrm{D}$ onion skin mempermudah proses in between setelah adanya keyframe. Hal ini memungkinkan untuk melihat frame by frame sebelum atau sesudah keyframe.

\section{UPT Perpustakaan ISI Yogyakarta}




\section{b. Coloring}

Tahap pewarnaan yang akan dilakukan di software digital imaging diselaraskan dengan ide visual sesuai dengan konsep.

\section{c. Render by shot}

Rendering per shot akan mempermudah mengamati satu kesatuan utuh dalam satu frame dengan durasi pendek sehingga apabila terjadi kesalahan revisi bisa langsung dikerjakan. Selain itu render per shot akan mempermudah pada tahap selanjutnya.

d. Background

Background tempat disesuaikan dengan karakter dan tema sedemikian rupa sehingga terlihat harmonis dan menyatu. Penggunaaan tekstur klasik untuk menambahkan kesan artistik sekaligus sebagai penguat suasana yang dibangun dalam cerita.

e. Background Music

Penggunaan background music menyamakan tempo gerakan animasinya dirasa cukup membantu dalam membangun emosional.

\section{f. Sound Effect}

Sound effect yang diterapkan sesuai dengan kebutuhan, semisal suara deburan air dan angin dengan cara menggunakan bantuan foley.

\section{UPT Perpustakaan ISI Yogyakarta}




\section{Pascaproduksi}

\section{a. Compositing}

Setelah rendering selesai dilakukan, tahap selanjutnya adalah menggabungkan animasi dengan background tersebut dengan teknik compositing. Mengatur bagaimana baiknya sehingga nampak menyatu dengan memberikan efek khusus digital seperti penggunaan grading dan pencahayaan tambahan.

\section{b. Editing}

Unsur audio mulai dari background music, sound effect serta foley disatukan dengan hasil visualisasi.

\section{c. Rendering}

Setelah semua alur pembuatan animasi sudah selesai, selanjutnya adalah rendering, menjadikan karya animasi ke format video. Mulai dari logo ISI Yogyakarta, logo Program Studi Animasi, logo studio, judul karya, isi karya animasi, dan credit title.

d. Mastering

Terakhir karya dibakar dalam piringan $D V D$. Karya yang telah dibakar dalam DVD, nantinya akan dikemas menggunakan DVD case berwarna transparan.

\section{UPT Perpustakaan ISI Yogyakarta}

